\title{
Twelfth Cranial Nerve Involvement in Guillain-Barre Syndrome: A Case Report
}

\author{
Guillain-Barré Sendromunda On İkinci Kraniyal Sinir Tutulumu:
} Olgu Sunumu

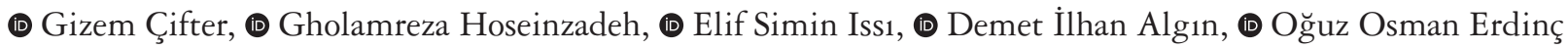
Eskisehir Osmangazi University Faculty of Medicine, Department of Neurology, Eskisehir, Turkey

\begin{abstract}
Guillain-Barre syndrome (GBS) is a common neurologic disease with paresthesia, albuminocytologic dissociation in cerebrospinal fluid analysis, accompanied by motor weakness, areflexia/hyporeflexia and mild sensory loss. Cranial nerve involvement is seen in $45-75 \%$ of patients with GBS. Of all cranial nerves, the $12^{\text {th }}$ cranial nerve is the most rarely involved nerve and very few cases have been described in the literature. This case is presented because it is an atypical case with hypoglossal nerve involvement, as well as significant asymmetric impairment of the upper extremities.
\end{abstract}

Keywords: Guillain-Barre syndrome, hypoglossal nerve, cranial nerve involvement

$\ddot{\mathbf{O z}}$

Guillain-Barre sendromu (GBS), motor güçsüzlük, arefleksi/hiporefleksi, hafif duyusal kaybın eşlik ettiği parestezi, beyin-omurilik sıvısında albümino-sitolojik dissosiyasyon ile seyreden ve sık karşılaşılan bir nörolojik hastalıktır. GBS'de kraniyal sinir tutulumu olguların \%45-75'inde görülür. Tüm kraniyal sinirler içinde en nadir tutulan sinir 12. kraniyal sinir olup, literatürde bugüne kadar çok az sayıda olgu tanımlanmıştır. Bu olgu hipoglossal sinir tutulumu yanı sıra üst ekstremitelerde belirgin asimetrik seyriyle atipik bir olgu olması nedeniyle sunulmuştur.

Anahtar Kelimeler: Guillain-Barre sendromu, nervus hipoglossus, kraniyal sinir tutulumu

\section{Introduction}

Guillain-Barre syndrome (GBS) is an acute inflammatory polyneuropathy characterized by rapidly progressing symmetrical muscle weakness and loss of deep tendon reflexes (DTR). It usually starts with weakness in the lower extremities, and within hours to days, it rises to the arms, face, oropharyngeal muscles, and in patients with severe disease, the respiratory muscles. An increase in protein (albuminocytologic dissociation) without cells is observed in the cerebrospinal fluid (CSF). Electrophysiologic examinations can show demyelinating and axonal damage (1).

Cranial nerve involvement in GBS is found in $45-75 \%$ of patients. The most affected nerve is the 7 th cranial nerve (Nervus facialis), and the nerves innervating the extraocular muscles $\left(3^{\text {rd }}\right.$, $4^{\text {th }}$ and $6^{\text {th }}$ cranial nerves); the lower cranial nerves are less affected (1). Among all cranial nerves, the most rarely involved nerve is the $12^{\text {th }}$ cranial nerve (Nervus hypoglossus), and thus far very few patients with GBS with hypoglossal nerve involvement have been described in the literature $(2,3,4,5,6,7,8)$.

\section{Case Report}

The patient's consent was obtained for sharing the clinical information and images.

A 34-year-old female patient presented with numbness and weakness that started in her right foot and progressed to the right arm and left half of the body within days. There was no feature in the medical and family history of the patient, and there was no drug use.

It was learned that the patient's symptoms started with numbness in her right foot 2 weeks before admission, which spread from her right foot to her right hand and then to the left leg and arm. It was observed that the patient, who was first admitted to an external center, revealed no pathology that could explain her symptoms in the contrast-enhanced cranial and spinal magnetic

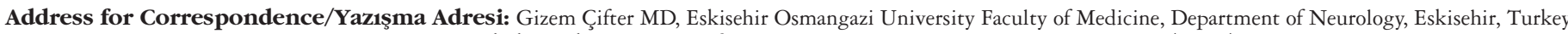
Phone: +90 55563610 86 E-posta: gzmcftr@gmail.com ORCID: orcid.org/0000-0001-5842-9342

Received/Geliş Tarihi: 25.12.2019 Accepted/Kabul Tarihi: 01.07.2020

${ }^{\circ}$ Copyright 2020 by Turkish Neurological Society

Turkish Journal of Neurology published by Galenos Publishing House. 
resonance imaging (MRI) examinations. It was learned that the electroneuromyography (ENMG) performed on the $5^{\text {th }}$ day of her symptoms at an external center was found to be normal. In the lumbar puncture performed on the $4^{\text {th }}$ day of her symptoms for research purposes, the protein level was $56 \mathrm{mg} / \mathrm{dl}$ in the CSF examination and no cells were detected. It was learned that the patient, who had no obvious pathology in the examinations, was discharged and followed up. The patient, who started to have difficulty in swallowing solid foods within a few days, was admitted to our center from the emergency department due to an increase in swallowing difficulties, and difficulty in swallowing liquid foods developed later.

In the neurologic examination, the patient was conscious, in good general condition, oriented, and cooperative. When the patient's tongue was out, it deviated to the left (Figure 1). The

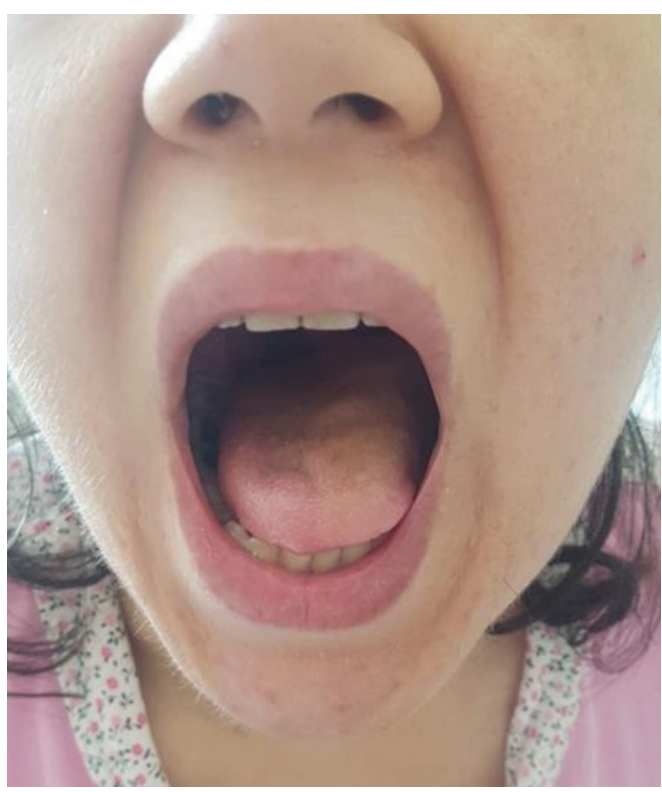

Figure 1. Left hypoglossal nerve involvement palatal arches were symmetrical and the gag reflex was positive. Other cranial nerve examinations were normal except for the left $12^{\text {th }}$ cranial nerve. Left upper extremity muscle strength was $2 / 5$, right upper extremity muscle strength was $5 / 5$, bilateral lower extremities' proximal muscle strength was $5 / 5$, and bilateral foot dorsiflexion muscle strength was $3 / 5$. She had steppage walking. DTR were absent in the upper and lower extremities. There was mild hypoesthesia in the distal parts of all four extremities.

No pathology was detected in the cranial computed tomography (CT) and diffusion MRI examinations performed in the emergency department, and no diffusion restriction was observed suggestive of ischemia. The cervical and thoracic MRI examinations of the patient performed in an external center were also considered normal.

Although ENMG was normal in the external center, ENMG was repeated on the $13^{\text {th }}$ day of her symptoms and it was found to be compatible with axonal-type sensorimotor polyneuropathy with marked asymmetric diffuse sensory and motor involvement in the lower extremities (Table1, Figure 2, 3).

The patient, who was hospitalized in our clinic with a prediagnoses of polyneuropathy, polyradiculitis, mononeuropathy multiplex, revealed no significant features in the hemogram and urine tests. Electrolyte values, erythrocyte sedimentation, C-reactive protein, vitamin B12 and folate levels were in the normal range. Tumor markers were evaluated within normal limits in terms of a paraneoplastic process, and no pathology was found in thoracic and abdominal CT. No infectious pathology was detected in the patient, who was evaluated in terms of Lyme's disease, Brucella, syphilis, and other infectious markers. Serum antinuclear autoantibodies were negative. Antineutrophil cytoplasmic autoantibodies (c-ANCA, p-ANCA), rheumatoid factor, and lupus anticoagulant were negative. Serum complement levels were normal. Immunofixation electrophoresis was normal in urine and blood, and there was no sign of monoclonal gammopathy. Anti-ganglioside antibodies could not be measured for technical reasons.

Although there were clinically asymmetric findings, acute motor and sensory axonal polyneuropathy (AMSAN) was

Table 1. Nerve conduction study findings of the patient

\begin{tabular}{|c|c|c|c|c|}
\hline Peripheral Nerve & Distal latency $(\mathrm{m} / \mathrm{sn})$ & Amplitude ( M-mV/S-uV) & Nerve conduction velocity (m/sn) & F-M latency (ms) \\
\hline Median motor right & 5.09 & 1.08 & 59.8 & 25.9 \\
\hline Median motor left & No response & No response & No response & No response \\
\hline Ulnar motor right & 2.28 & 1.89 & 64.9 & 29.8 \\
\hline Ulnar motor left & 2.12 & 1.58 & 58.6 & 32.9 \\
\hline Peroneal motor right & No response & No response & No response & No response \\
\hline Peroneal motor left & No response & No response & No response & No response \\
\hline Tibial motor right & 4.58 & 0.68 & 52.1 & No response \\
\hline Tibial motor left & 4.86 & 0.46 & 48.2 & No response \\
\hline Median sensory right & - & - & - & - \\
\hline Median sensory left & - & - & - & - \\
\hline Ulnar sensory right & - & - & - & - \\
\hline Ulnar sensory left & - & - & - & - \\
\hline Sural sensory right & 2.98 & 9.3 & 44.1 & - \\
\hline Sural sensory left & 2.59 & 5.8 & 52.1 & - \\
\hline
\end{tabular}




\begin{tabular}{|c|c|c|c|c|c|c|c|c|}
\hline \multicolumn{9}{|l|}{ Nerve conduction studies } \\
\hline \multicolumn{9}{|l|}{ Motor \& sensory NCS } \\
\hline \multirow{2}{*}{ Nerve } & \multicolumn{2}{|r|}{ Lat } & \multicolumn{2}{|c|}{ Amp } & \multicolumn{2}{|r|}{ CV } & \multicolumn{2}{|r|}{ F-M lat } \\
\hline & ms & Ref. dev & M-mV/SuV & Ref. dev & $\mathbf{m} / \mathbf{s}$ & Ref. dev & ms & Ref. dev \\
\hline \multicolumn{9}{|l|}{ Left median motor } \\
\hline Wrist - APB & - & & - & & & & & \\
\hline Elbow - wrist & - & & - & & - & & & \\
\hline \multicolumn{9}{|l|}{ Right median motor } \\
\hline Wrist - APB & 5.09 & & 1.08 & & - & & & \\
\hline Elbow - wrist & 9.27 & & 0.10 & & 59.8 & & & \\
\hline \multicolumn{9}{|l|}{ Left median sensory } \\
\hline Dig II - wrist & - & & - & & & & & \\
\hline \multicolumn{9}{|l|}{ Right median sensory } \\
\hline Dig II - wrist & - & & - & & - & & & \\
\hline \multicolumn{9}{|l|}{ Left peroneal motor } \\
\hline Ankle - EDB & - & & - & & & & & \\
\hline Bl. knee - ankle & - & & - & & - & & & \\
\hline \multicolumn{9}{|l|}{ Right peroneal motor } \\
\hline Ankle - EDB & - & & - & & . & & & \\
\hline Bl. knee - ankle & - & & - & & - & & & \\
\hline \multicolumn{9}{|l|}{ Left sural sensory } \\
\hline Mid. lower leg - lat. malleolus & 2.59 & & -5.8 & & 52.1 & & & \\
\hline \multicolumn{9}{|l|}{ Right sural sensory } \\
\hline Mid. lower leg - lat. malleolus & 2.98 & & 9.3 & & 44.1 & & & \\
\hline \multicolumn{9}{|l|}{ Left tibial motor } \\
\hline Ankle - Abd hal & 4.86 & & 0.68 & & & & & \\
\hline Knee - Ankle & 14.2 & & 0.46 & & 40.7 & & & \\
\hline \multicolumn{9}{|l|}{ Right tibial motor } \\
\hline Ankle - Abd hal & 19.9 & & - & & - & & & \\
\hline Knee - ankle & - & & - & & - & & & \\
\hline \multicolumn{9}{|l|}{ Right ulnar motor } \\
\hline Wrist - ADM & 2.28 & & 1.89 & & & & & \\
\hline Bl. elbow - wrist & 6.04 & & 1.58 & & 69.1 & & & \\
\hline Ab. elbow - Bl. elbow & 7.58 & & 1.52 & & 64.9 & & & \\
\hline \multicolumn{9}{|l|}{ Left ulnar sensory } \\
\hline Dig V - wrist & - & & - & & & & & \\
\hline
\end{tabular}

Figure 2. Electroneuromyography findings

principally considered because the examinations for vasculitis were normal, there were no systemic findings, and no obvious neuropathic pain was identified. A nerve biopsy was planned according to the clinical follow-up of the patient.

Intravenous immunoglobulin (IVIG) at a dose of $0.4 \mathrm{~g} / \mathrm{kg}$ was started in the patient, who was diagnosed as having GBS. During the treatment process, the patient's neurologic examinations showed deterioration, and the right upper extremity muscle strength was $4 / 5$ and bilateral foot dorsiflexion was $2 / 5$. The patient, who started to describe low back pain and severe tinglingstinging in the arms, was given $150 \mathrm{mg} /$ day of pregabalin, which was given in 2 doses per day, for her paresthesia. After two days of IVIG treatment, IVIG treatment was discontinued due to increased creatinine in the blood, and plasmapheresis was initiated. After seven days of plasmapheresis, no improvement was observed in the $12^{\text {th }}$ cranial nerve paralysis of the patient whose left upper extremity muscle strength was $3 / 5$ and bilateral foot dorsiflexion was $3 / 5$. The patient was discharged with a recommendation for physical therapy.

\section{Discussion}

GBS is an autoimmune disease. Peripheral nerve damage is caused by the direct effect of infection or by autoantibodies produced from T-cells and B-cells triggered by immunologic mediators. It usually begins with numbness followed by weakness in the lower extremities and progresses from the bottom up within a few days. Symptoms, particularly weakness, can progress rapidly and result in quadriplegia. Of all patients, $50 \%$ reach the point of maximum weakness within 2 weeks, $80 \%$ within 3 weeks, and $90 \%$ within 4 weeks (9). Deterioration over four weeks is unexpected and should suggest other diagnoses. Multifocal inflammatory demyelination of the spinal roots and peripheral nerves underlies the pathology of GBS, and because it is a polyradiculoneuropathy, weakness may be more pronounced in the proximal muscles. However, in most 


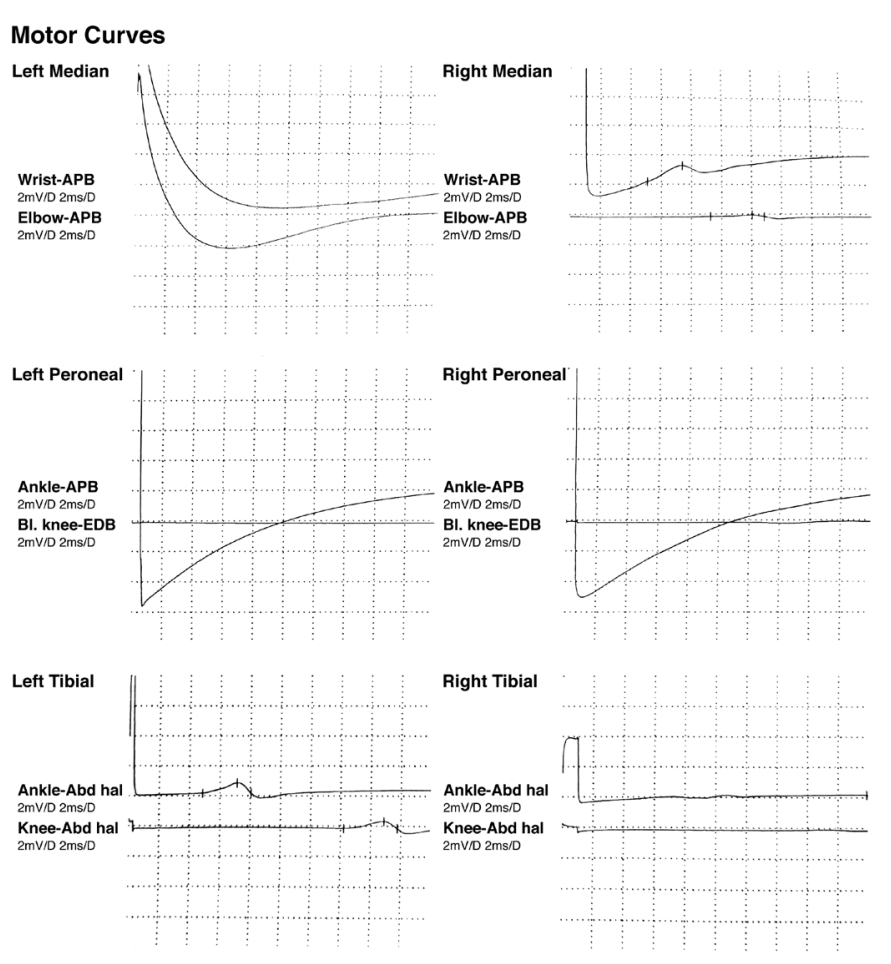

Figure 3. Electroneuromyography findings

cases, the weakness starts from the proximal muscles and spreads to the distal muscles.

Cranial nerve involvement is observed in $45-75 \%$ of patients with GBS. The most affected nerve is the $7^{\text {th }}$ cranial nerve (Nervus facialis), some facial weakness develops in approximately $50 \%$ of patients, and other cranial nerves may be affected during the course of the disease (1). Ophthalmoparesis has been reported in approximately $20 \%$ of patients with GBS (10). Cranial nerves located at the lower levels are the least affected (1). The $12^{\text {th }}$ cranial nerve (Nervus hypoglossus) is the least involved nerve among all the cranial nerves, and very few patients with GBS with hypoglossal nerve involvement have been described in the literature to date $(2,3,4,5,6,7,8)$.

Tan and Chee (2) reported a patient with severe GBS who presented with quadriplegia complicated by complete involvement of multiple motor cranial nerves, including the $12^{\text {th }}$ cranial nerve. Polo et al. (3) reported a 23-year-old male patient who had atypical and fulminant GBS with multiple cranial nerve involvement including the $12^{\text {th }}$ cranial nerve and diplopia, facial diplegia, nasal voice, neck and tongue muscle weakness, dysphagia, and areflexia in the upper extremities, without involvement of the lower extremities. Nanda et al. (8) reported a 13-year-old male patient with GBS who had bulbar weakness, bilateral facial involvement and hypoglossal nerve involvement, and anti-ganglioside antibodies were found to be positive. In these case reports, patients in a relatively younger age group were reported and features such as nasal voice and dysphagia, indicating both hypoglossal and other lower cranial nerve involvement, were reported. Respiratory support was also required in two of these patients. Chakrabarti and Pan (6) reported a relatively mild course of GBS in a 38 -year-old male patient, starting from the lower extremities and rising upwards, progressing with unilateral facial and hypoglossal involvement and improving without the need for ventilator support. Eswaradass et al. (7) recently reported a 21 -year-old patient with GBS with right $7^{\text {th }}$ and $12^{\text {th }}$ cranial nerve involvements and right medial rectus muscle weakness.

AMSAN is a rare and severe GBS subtype that accounts for only 3-5\% of all patients with GBS in Western countries. AMSAN usually shows severe symptoms within a short time and recovery is usually long and inadequate compared with other forms of GBS (7).

In a small number of patients reported in the literature, the hypoglossal nerve involvement seen in GBS was not isolated, and was usually accompanied by $7^{\text {th }}, 9^{\text {th }}$, and $10^{\text {th }}$ cranial nerve involvements. Although no additional cranial nerve involvement was detected in our patient, there might have been additional involvement due to the presence of dysphagia. Our patient was evaluated as atypical due to the hypoglossal nerve involvement, as well as its prominent asymmetric course in the upper extremities.

Ethics

Informed Consent: The patient's consent was obtained for sharing the clinical information and images.

Peer-review: Externally and internally peer-reviewed.

\section{Authorship Contributions}

Surgical and Medical Practices: G.Ç., G.H., D.İ.A., Concept: D.İ.A., O.O.E., Design: E.S.I., G.Ç., Data Collection or Processing: G.Ç., G.H., Analysis or Interpretation: : G.Ç., E.S.I., D.İ.A., O.O.E., Literature Search: G.Ç., Writing: G.Ç.

Conflict of Interest: No conflict of interest was declared by the authors.

Financial Disclosure: The authors declared that this study received no financial support

\section{References}

1. Bradley WG, Daroff RB, Fenichel GM, Jankovic J. Neurology in Clinical Practice, Vol.2. 5th ed. Philedelphia: Elsevier Inc, 2007.

2. Tan AK, Chee MW. Fulminant Guillain Barré syndrome with quadriplegia and total paresis of motor cranial nerves as a result of segmental demyelination. J Neurol Sci 1995;134:203-206.

3. Polo JM, Alañá-García M, Cacabelos-Pérez P, et al. Atypical Guillain Barré syndrome: Multiple cranial neuropathy. Rev Neurol 2002;34:835-837.

4. Keane JR. Twelfth-nerve palsy: Analysis of 100 cases. Arch Neurol 1996;53:561-566.

5. Pratim CP, Dipanjan B, Kumar MS, Subhasis RC, Ramtanu B. Unilateral XIIth cranial nerve palsy as the only presenting symptom of Guillain- Barre syndrome - a case report. Case Rep Clin Pract Rev 2005;6:251-254.

6. Chakrabarti S, Pan K. Hypoglossal nerve palsy in a case of Guillain Barré syndrome. Ann Trop Med Public Health 2014;7:270.

7. Eswaradass PV, Ramasamy B, Kalidoss R, Gnanashanmugham G. A rare cause of twelfth nerve palsy: Guillain-Barré Syndrome. Arch Med Health Sci 2017;5:140-141.

8. Nanda SK, Jayalakshmi S, Ruikar D, Surath M. Twelfth cranial nerve involvement in Guillain Barré Syndrome. J Neurosci Rural Pract 2013;4:338-340.

9. Donofrio PD. Guillain-Barré Syndrome. Continuum (Minneap Minn) 2017;23(5, Peripheral Nerve and Motor Neuron Disorders):1295-1309.

10. Ropper A. The Guillain Barré Syndrome. N Eng J Med 1992;326:11301136 